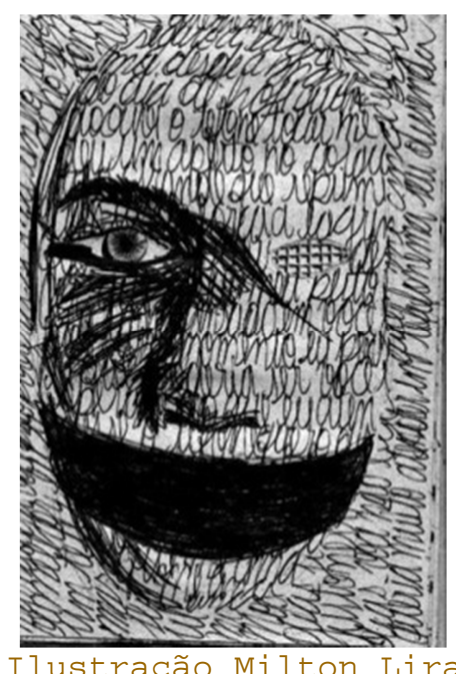

\title{
A exclusão digital e a leitura literária no Brasil
}

\section{Marcelo Chiaretto}

Marcelo Chiaretto é doutor em Literatura Comparada pela Faculdade de Letras da UFMG, professor na mesma Faculdade e no COLTEC/UFMG e membro do Programa A tela e o texto.

\section{Resumo}

Este trabalho investiga a ligação existente entre exclusão digital e literatura no Brasil, visando assim estabelecer uma conexão mais dialógica e menos monolítica entre o leitor e o texto digital. O trabalho também inclui algumas sugestões para a mudança dos paradigmas que comumente buscam refletir sobre a presença da literatura e da televisão na escola e na sociedade.

Palavras-chave: exclusão digital, leitura literária, democracia no Brasil.

Seria instigante dar início a este artigo fazendo breves reflexões sobre o problema levantado pelo tema provocador desta revista, qual seja, a possibilidade da televisão prejudicar a leitura. De fato, é decepcionante e até mesmo entristecedor parar para pensar nisso. Na realidade, lembrando e modificando uma frase de Michel Foucault, presente na obra As palavras e as coisas, o rosto que a televisão reflete é igualmente aquele que o contempla. 
É, grosso modo, o que acontece na leitura de um livro. Inadvertidamente a TV olha e é olhada, permitindo assim um espaço grande para a reciprocidade. Tal condição, todavia, é na maioria das vezes negligenciada, pois a TV - o mundo que ela constrói, assim como sua linguagem - assume quase sempre uma postura de representação e exclusão. Essa percepção é frustrante, sobretudo quando se nota que a TV poderia ser - ou poderia instaurar - um espetáculo de olhares, que dariam liberdade para uma leitura que se poderia chamar de literária, bem de acordo com o que pensavam os teóricos da Estética da Recepção. No entanto, a atuação desse super-eletrodoméstico é predominantemente impositiva, o que torna seu receptor acanhado e distante. E dada a presença maciça nos lares, tal estilo de recepção é sempre multiplicado, o que remete ao fato óbvio que marca a contemporaneidade: quem está longe da TV está fora do ar em muitos sentidos.

O objetivo nesta oportunidade não seria obviamente condenar a televisão enquanto veículo midiático. O problema estaria na sua instauração abertamente excludente. A modernidade oferece também o acesso ao mundo virtual. Porém, o que talvez leve a uma preocupação crescente é que esse novo mundo explicita outra modalidade de exclusão no setor áudio-visual. Para se compreender tal processo na contemporaneidade, seria relevante atentar-se, primeiramente, para um artigo de jornal publicado por um grande empresário do Brasil. Tendo por base uma análise da revista britânica the economist, o empresário Antônio Ermírio de Moraes publicou na Folha de São Paulo de 17 de junho de 2001 um artigo em que tenta orientar a organização da sociedade moderna no Brasil. Era um domingo, dia em que este veículo de informação alcança quase um milhão de exemplares vendidos.

o empresário é enfático ao dizer que "entre milhões que se perdem nas drogas e na marginalidade, é da juventude que está surgindo a revolução no conhecimento". Segundo ele, a sociedade moderna conta com os jovens e depende deles. Daí, para quem vai herdar um planeta, nada mais valioso do que ser bem-educado, pois, afinal de contas, para Antônio Ermírio, no mundo profissional competência é um requisito essencial, mas zelo pelo trabalho é ainda mais importante. Concluindo a partir do artigo em questão, há um grande desafio para as escolas de hoje: não basta informar, é preciso formar.

Vê-se que o empresário parte da leitura de uma revista especializada em economia e mercado para endossar um posicionamento claro: para que seja de fato moderna, a sociedade brasileira está necessitando cada vez mais de bons profissionais, isto é, de jovens que respeitem seu trabalho, de forma cordata, com espírito humanitário e familiar, compreendendo certamente seu lugar na hierarquia da sociedade, 
sabendo servir e receber ordens de maneira educada, pois "grande será o resultado se tirarmos das trevas os que estão impedidos de entender a natureza e a humanidade" (1).

É difícil imaginar o espaço para a literatura em uma escola concebida nos moldes supracitados. Uma escola encarada apenas como Instituição (con)formadora de mão de obra não pode perder tempo com debates, incertezas ou outros traços subjetivistas, uma vez que as mudanças na ciência, na economia e na tecnologia estão atropelando todos os resquícios do dia passado repleto de dúvidas. Pierre Lévy já chegou a imaginar uma espécie de tecnodemocracia, com o hipertexto rompendo fronteiras no contexto da globalização econômica. Entretanto, quando se percebe a realidade brasileira e suas fronteiras cada vez mais bem demarcadas - até mesmo e sobretudo no que tange ao plano externo - , o que se vê é uma perspectiva pouco simpática de dominação cultural, controle social e exaltação dos mais favorecidos economicamente. É O tempo da digitalização.

No mesmo jornal e no mesmo domingo, Gilberto Dimenstein parece suplementar o pensamento pragmático do empresário. No artigo intitulado "O ex-presidente Clinton e a professora do Ceará", - jornalista descobre o que talvez seja o maior risco para a formação em série deste jovem profissional educado e servil: a exclusão digital, ou seja, a legião dos sem computador que atrapalham o progresso das nações na era da informação. Preocupado com os desencantados jovens digitalmente excluídos - e se esquecendo da imensa multidão de professores sem condições de reciclagem profissional, sem disposição psicológica, sem esperança de reconhecimento social e sem cadeiras para acomodar os seus alunos socialmente excluídos Gilberto Dimenstein (2001) comenta:

A eficiência das sociedades está ancorada, em larga medida, na sua capacidade de compartilhar conhecimento e, por conseqüência, de disseminar os códigos de informática. O analfabeto digital é um pária condenado à marginalidade: não contribui ao enriquecimento da comunidade e, pior, vai depender de algum tipo de assistência. (2)

Diante das palavras do jornalista, certamente lidas e assimiladas por uma quantidade imensa de leitores, não há como discordar sobre a necessidade atual de "disseminar os códigos de informática" para que se possa evitar o surgimento de uma nova classe de excluídos. O problema estaria em entender o ato de "ensinar melhor" tendo como obstáculo o educador despreparado, exaurido, incapaz e, principalmente, sem computador.

o professor digitalmente excluído, sob essa ótica, seria um entulho a ser varrido pela era moderna, o tempo da velocidade 
e da técnica, proporcionado pela tecnologia que repudia qualquer desrazão ou desinformação. Em um Editorial da própria Folha de São Paulo que justificava a existência de novos padrões de produção e transmissão de conhecimento, um dos membros do Conselho chega a mencionar: "as tecnologias que aumentam cada vez mais a velocidade da transmissão de dados sugerem também uma realidade social e cultural próxima do ritmo dos impulsos cerebrais" (3).

Desse modo, pode-se deduzir que a busca pelo conhecimento, ou então, a ânsia por evitar a exclusão do conhecimento nos tempos atuais, se antes passava pela desnacionalização, hoje passa pela desnaturalização do sujeito e de sua realidade social, produto da ultra-aceleração provocada pela informática e pelos meios de comunicação. Em vista do essencial celebrado por Antônio Ermírio, Gilberto Dimenstein e pelo membro do Conselho Editorial do jornal citado, descobre-se que a força humana erótica e vital está sendo cada vez mais direcionada para o trabalho imediato, cronologicamente projetado, fazendo da velocidade uma espécie de droga que paulatinamente reduziria o prazer no sexo, na amizade, no próprio trabalho e, sobretudo, nas escolas.

\section{o poder do jogo}

É pertinente remeter-se aqui ao historiador holandês Johan Huizinga. Em sua obra Homo Ludens (1980), ele demonstra, a partir da relação do ser humano com a idéia de brincadeira, que a cultura e a própria civilização podem ser vistas como o resultado de um jogo. As mais diversas atividades humanas, dentre elas linguagem, filosofia, leis, teriam como fundamento as evoluções de brincadeiras. Em todas as dimensões, haveria espaço para competições, ilusões, divertimentos e mesmo espaço para matar o tempo, em um desafio à realidade agora deslocada ao bel prazer. A escrita, como caso particular, poderia ser vista como um mix lúdico de sons, símbolos e significados, onde $O$ leitor não apenas encontraria aquilo que ele objetivamente buscaria - no caso de uma leitura funcional - , mas também perceberia a sua voz, o seu olhar, sem intervenção mecanizada, sem padrão pré-estabelecido, sem tempo nem hora de informar ou revelar. É a própria leitura literária referida na introdução deste artigo, que concede espaço para o receptor e que, enquanto processo social e individual, concede tempo para a imprevisibilidade do sujeito leitor, respeitando sua carga subjetiva conformada em experiências, sentimentos, pensamentos e desejos sem nenhum juízo.

É relevante destacar neste momento que a intenção ora explicitada não seria a de negar a digitalização e a modernidade em sua visão de progresso e de velocidade. Como disse Milton Santos: 
Aqui não se trata de pregar o desconhecimento da modernidade - ou uma forma de regresso ao passado - , mas de encontrar as combinações que, segundo as circunstâncias próprias a cada povo, a cada região, a cada lugar, permitem a construção do bem-estar coletivo. É possível dispor da maior velocidade tecnicamente possível no momento e não utilizá-la. É possível fruir da modernidade nova, atual, sem ser obrigatoriamente o mais veloz.(4)

Conforme uma visão dominante, afinam-se os livros, reduzem-se períodos e capítulos, montam-se narrativas simplificadas e superficiais, firmando a virtude nos livros produtores de leitura tecnicamente veloz e econômica. No mundo de hoje, as obras literárias parecem ter que optar por serem recipientes ou de informação ou de entretenimento. Torna-se assim mais do que fundamental a atenção às concepções de estudiosos como Roland Barthes, que enfatiza a opção de se encontrar a virtude no ato de se poder ler levantando às vezes os olhos, interrompendo com freqüência a leitura não por desinteresse mas, ao contrário, por afluxo de idéias, excitações, associações: "é essa leitura, ao mesmo tempo desrespeitosa, pois que corta o texto, e apaixonada, pois que a ele volta e dele se nutre" (5). É uma leitura sem a imposição do tempo, sem autoridade, que reencontra a perspectiva do prazer no momento da hesitação e do estranhamento, levando ao conhecimento de si mesmo e do mundo.

Em conformidade com os pensamentos de Adorno, o poder da racionalidade instrumental não está simplesmente em estabelecer verdades: seu poder está em reduzir toda racionalidade ao "ou isto ou aquilo", sempre uma alternativa entre a ordem vigente e um grande disparate. É o momento de relembrar Huizinga e sua noção de brincadeira que confunde a ordem e o disparate.

Quando se coloca em discussão o teor ideológico do mundo da tecnologia, o estudioso holandês parece abrir as portas para certas inquirições de Herbert Marcuse (1969). Na sociedade moderna, é urgente retomar a perspectiva do prazer na escola sem que sejam indispensáveis mediações disciplinadoras. Conforme destacou o filósofo alemão, o ser humano começou a ter dificuldades de sentir gozo em suas atividades cotidianas no momento em que perdeu o poder de se relacionar abertamente com o outro. Tal fato teria ocorrido devido a uma percepção amplamente simplificada e objetivista do mundo exterior, uma vez que o mundo interior do sujeito logrou reproduzir o cálculo, a frieza e o distanciamento exaltados pela razão e pelo trabalho intermediado por máquinas. Para reencontrar o prazer, não é necessário assumir-se radicalmente como um excluído digital. Para reencontrar o prazer realmente, seria fundamental abrir mão de atitudes mecânicas, não fomentar sentimentos de incompetência e desqualificação - como se todos vivêssemos em um grande e inescapável mercado - e olhar o 
outro com mais atenção e menos desinteresse, como se olhasse a página de um livro.

A escola, pelo seu potencial de unir coletividades com pensamentos e idéias diferenciados, sendo uma instituição com um ponto de vista mais atento aos fenômenos cognitivos e despreocupada com a tradicional disciplina, representaria um grande papel nesse processo de recuperação das relações pessoais, nesse processo de revigoração da imaginação, da capacidade poética e lúdica. Seria um ótimo antídoto contra o discurso impessoal que impera nos contatos insuflados pela Internet. Segundo um ponto de vista fiel às sugestões da tecnologia digital, bate-papo, namoro e sexo pelo computador podem substituir a intimidade dos relacionamentos, já que basta buscar outro site para que uma nova relação - e novos parceiros - surjam nos monitores. É fundamental assim repensar a neutralidade da técnica, pois a tecnologia realmente deve ser inserida nas escolas assim como já está na sociedade, porém sem que, o que é primordial, seja perdida a perspectiva humanista que dá esteio a todo processo de fato educacional.

\section{o cheiro do papel e da tinta}

A 17a. Bienal Internacional do Livro de São Paulo, ocorrida em abril de 2002, possibilitou conclusões interessantes. Com efeito, há ainda muitos que temem uma substituição do livro convencional pelo eletrônico. Entretanto, como informou Elio Demier (proprietário da Editora Bom Texto, uma das editoras de maior comercialização de e-books no Brasill, a baixa rentabilidade observada neste mercado - em uma situação vivida até nos Estados Unidos - explica-se por certos traços do livro convencional que escapam aos avanços tecnológicos: "O livro de papel tem forma, cheiro, manuseio, coisas que atraem e prendem o leitor. O que terá o e-book para prender o leitor?" (6).

Nota-se que não há espaço para a substituição, mas para a convivência. Sem negar a modernidade e sua tecnologia, percebe-se como urgente o encontro de combinações, de alternativas, de uma convivência democrática e interativa entre 0 visto como novo e o divulgado como antigo. Profissionais do ensino sem computador não podem ser vistos como culpados pela ignorância digital dos alunos, não são párias a trabalhar no escuro, mas trabalhadores com direito de seguir outros caminhos, com direito de contribuir com o seu saber no processo lento que será este, o processo de inclusão do conhecimento digitalizado na sala de aula.

- historiador norte-americano Robert Darnton se disse horrorizado quando soube que o projeto original para um novo campus da Universidade da Califórnia em Monterrey nem sequer incluía uma biblioteca. Para ele: 
Imaginamos as bibliotecas como o núcleo de nossos campi, mas esse seria um novo campus sem uma biblioteca. Os projetistas julgaram que os computadores seriam suficientes, supostamente porque acreditavam que os livros nada mais fossem que recipientes de informação. Hoje muitos estudantes adotam essa atitude, e não só na Califórnia. Acham que pesquisar é surfar. Quando escrevem trabalhos, costumam surfar na Internet, baixar os arquivos, recortar, colar e imprimir. Se tal nos fornece um relance do futuro, é o quanto basta, a meu ver, para tornar a pessoa um opositor diante da mudança tecnológica. (7)

Darnton também acredita na combinação entre digitalização e impressão. Todavia, levando em conta o livro tradicional, sua respectiva história e sobretudo sua leitura, o historiador não se vexa ao dizer: "preservem o livro, cerrem fileiras pela biblioteca". Seria uma boa estratégia para resguardar a calma na leitura literária, o cheiro do papel e os contatos interpessoais dentro e fora da escola em prol de um futuro mais construtivo, democrático e aberto às diferenças.

\section{Abstract}

This work investigates the relationship between digital exclusion and literature in Brazil, in order to find a more dialogical and wider connection between reader and digital text. We also suggest that we should change our way of thinking literature and television in society and, more specifically, in school.

Key-words: digital exclusion, reading of literature, democracy in Brazil.

\section{Notas}

(1) MORAES, 2001.

(2) DIMENSTEIN, 2001.

(3) Folha de S. Paulo, 2002.

(4) SANTOS, 2001, p. 12.

(5) BARTHES, 1984, p. 40.

(6) Apud ANGIOLILLO, 2002.

(7) DARNTON, 2001, p. 5 .

\section{Bibliografia}

ANGIOLILLO, Francesca. O livro de papel dá sustento ao eletrônico. Folha de S. Paulo, São Paulo, 11.maio 2002. Ilustrada, p. 5. 
BARTHES, Roland. O rumor da língua. Trad. Mário Laranjeira. São Paulo: Brasiliense, 1984 .

DARNTON, Robert. O poder das bibliotecas. Folha de S. Paulo, São Paulo, 15.abr.2001. Caderno Mais, p. 4-7.

DIMENSTEIN, Gilberto. O ex-presidente Clinton e a professora do Ceará. Folha de S. Paulo, São Paulo, 17.jun.2001. Cotidiano, p. 17.

FoUCAULT, Michel. As palavras e as coisas. Trad. Salma Muchail. São Paulo: Martins Fontes, 1992 .

HUIZINGA, Johan. Homo ludens: o jogo como elemento da cultura. Trad. J. P. Monteiro. São Paulo: Perspectiva, 1980.

LÉVY, Pierre. Cibercultura. Rio de Janeiro: 34, 1999. As tecnologias da inteligência. Rio de Janeiro: 34, 1993.

MARCUSE, Herbert. Eros e civilização: uma interpretação filosófica do pensamento de Freud. Trad. Álvaro Cabral, Rio de Janeiro: Zahar, 1969.

MORAES, A. E. de. Um importante incentivo à profissionalização. Folha de $S$. Paulo, São Paulo, 17.jun.2001. Brasil, p. 2.

PAZ, Octavio. Signos em rotação. São Paulo: Perspectiva, 1990.

SANTOS, Milton. Elogio da lentidão. Folha de S. Paulo, São Paulo, 11.mar.2001. Caderno Mais, p.14-15. 